\title{
Pengenalan Wajah Menggunakan Minimum Distance Classifier Berdasarkan Fitur Principal Component Analysis
}

\author{
Bella Adinda Putri*1, Saparudin ${ }^{2}$, Samsuryadi ${ }^{3}$ \\ ${ }^{1,3}$ Fakultas Ilmu Komputer, Universitas Sriwijaya, Palembang \\ 2Universitas Telkom, Bandung \\ e-mail: *1belladinda92@gmail.com, 2saparudin@telkomuniversity.ac.id, \\ ${ }^{3}$ samsuryadi@unsri.ac.id
}

\begin{abstract}
Abstrak
Penggabungan metode Principal Component Analysis (PCA) dan Minimum Distance Classifier dalam pengenalan wajah dapat bekerja dengan baik pada lebih dari satu dataset standar. Penambahan tahapan pre-processing berupa image enhancement di penelitian ini sangat berperan penting dalam memperbaiki kualitas citra input sehingga dapat memberikan akurasi yang lebih baik dari penelitian sebelumnya dengan tanpa memperlambat kerja sistem tersebut. Namun untuk mencapai tujuan tersebut, perlu dilakukan studi kepustakaan untuk memahami konsep dan landasan teori agar dapat memperkuat asumsi teknik image enhancement, metode Principal Component Analysis sebagai metode ekstraksi ciri, dan Minimum Distance Classifier sebagai metode pengenalan. Hasil pengenalan dengan menggunakan data uji dari ORL database mendapatkan keakuratan sebesar 97\%, sedangkan hasil pengenalan menggunakan data uji dari YALE database mendapatkan keakuratan sebesar 94,6\%. Sehingga dapat disimpulkan bahwa dengan penambahan teknik image enhancement di dalam penggabungan metode Principal Component Analysis dan Minimum Distance Classifier dapat memberikan solusi yang cepat dan sederhana dengan meningkatkan atau tanpa mengurangi akurasi standar.
\end{abstract}

Kata kunci- pengenalan wajah, image enhancement, ekstraksi ciri, principal componet analysis, minimum distance classifier

\begin{abstract}
The combination of Principal Component Analysis (PCA) and Minimum Distance Classifier methods in face recognition can work well on more than one standard datasets. The addition of pre-processing stages in the form of image enhancement in this study is very important in improving the quality of the input image so that it can provide better accuracy than previous studies without slowing down the system. However, to achieve this goal, it is necessary to conduct a literature study to understand the concepts and theoretical basis in order to strengthen the assumptions of image enhancement techniques, Principal Component Analysis as feature extraction method, and Minimum Distance Classifier as recognition method. Recognition result with ORL database get an accuracy of 97\%, while recognition result with YALE database get an accuracy of $94.6 \%$. So it can be concluded that the addition of image enhancement techniques in the combination of the Principal Component Analysis and Minimum Distance Classifier methods can provide a fast and simple solution by increasing or without reducing its standard accuracy.
\end{abstract}

Keywords - face recognition, image enhancement, feature extraction, principal componet analysis, minimum distance classifier 


\section{PENDAHULUAN}

Teknologi berbasis biometrik meliputi identifikasi berdasarkan karakteristik fisiologis seperti wajah, sidik jari, telapak tangan, iris, retina, telinga, suara, dan berdasarkan sifat-sifat perilaku seperti gaya berjalan, dan dinamika tanda tangan. Teknologi biometrik seperti ini cenderung membutuhkan tindakan sukarela oleh pengguna. Sedangkan, pengenalan wajah dapat dilakukan secara pasif tanpa tindakan eksplisit atau partisipasi dari pengguna, karena citra wajah dapat diperoleh dari jarak jauh dengan kamera [1].

Wajah manusia adalah salah satu pola biometrik yang paling umum dijumpai dalam sistem visual manusia. Seiring berkembangnya teknologi, pengenalan wajah adalah salah satu teknik keamananan yang paling banyak digunakan dalam bidang biometrik, karena memiliki potensi luas yang telah banyak diaplikasikan di dunia nyata, misalnya, video pemantau, sistem akses kontrol, forensik dan keamanan, jaringan sosial, dan berbagai bidang lainnya [2].

Penelitian dalam bidang pengenalan wajah memiliki nilai teoritis yang besar, yang melibatkan subyek pengenalan pola, pengolahan citra, computer vision, pembelajaran mesin, fisiologi, dan sebagainya, dan juga memiliki korelasi tinggi dengan metode pengenalan biometrik lainnya. Dalam beberapa tahun terakhir, pengenalan wajah adalah salah satu masalah yang paling aktif dan menantang di bidang pengenalan pola dan kecerdasan buatan [3].

Pengenalan wajah 2 dimensi (2D) biasanya mencakup 4 langkah, yang pertama adalah mendeteksi wajah, langkah kedua adalah penyelarasan wajah, langkah ketiga adalah ekstraksi fitur dan langkah keempat adalah pencocokan fitur dari basis data pengguna yang terdaftar untuk mengenali wajah tersebut. Matriks telah dihitung berdasarkan nilai piksel di sudut wajah di bawah kondisi pencahayaan berbeda untuk pengenalan wajah 2D. Biasanya, citra wajah diwakili oleh vektor dimensi tinggi yang mengandung nilai piksel. Pencocokan fitur dilakukan untuk mencocokkan wajah input dalam bentuk citra atau video dari database yang tersedia. Berbagai teknik yang diadopsi untuk deteksi wajah didasarkan pada warna, intensitas dan pencahayaan. Berbagai penelitian menghadapi banyak tantangan seperti ekspresi wajah, iluminasi, variasi pose dan oklusi. Ada beberapa batasan pengenalan wajah 2D. Dalam sistem pengenalan wajah $2 \mathrm{D}$, tingkat dan kinerja pengenalan tergantung pada kondisi pengambilan citra seperti orientasi kepala, kualitas citra, kondisi pencahayaan, oklusi partial, dan ekspresi wajah [4].

Penelitian oleh Zhou et al [3] mengenali wajah dengan mengklasifikasikan individu dalam kategori sasaran melalui fungsi logistik. Penelitian oleh Sharma \& Patterh [5] mengenali wajah berdasarkan nilai ambang yang telah ditetapkan oleh ANFIS. Lalu Bag \& Sanyal [6] menerapkan algoritma Minimum Distance classifier untuk mengenali wajah, dan kemudian Gawande \& Agrawal [7] melakukan perbandingan berbagai jenis Distance Classifier dengan menggunakan PCA sebagai pengekstaksi fitur yang kemudian membuktikan bahwa Minimum Distance Classifier lebih unggul dibanding Distance Classifier lainnya. Khan \& Gupta [8] melakukan penelitian tentang pengenalan wajah yang efisien berdasarkan algoritma ekstraksi sub-window dan algoritma PCA, dan dengan meningkatnya ketersediaan citra berwarna,

Sable \& Talbar [9] melakukan hal berbeda dalam pengenalan wajah melalui pendekatan untuk mengintegrasikan informasi warna ke dalam proses pengenalan. Pendekatan yang mempertimbangkan informasi intensitas serta informasi berwarna seperti ruang warna $\mathrm{YcbCr}$ pun diimplementasikan menggunakan PCA dan Wavelet Packet Decomposition. Kemudian Mondal \& Bag [10] telah mengusulkan PCA dengan Minimum Distance Classifier (MDC) untuk pengenalan wajah. Penelitian tersebut dilakukan pada basis data ORL dan basis data YALE. PCA dan MDC ketika diuji pada database ORL telah memberikan tingkat akurasi 95,63\% sedangkan kombinasi yang sama ketika diuji pada database YALE telah memberikan tingkat akurasi sebesar 93,33\%. 
Sebelumnya juga telah dilakukan penelitian untuk pengenalan citra buah dengan mengombinasikan PCA dan Minimum Distance Classifier dan mendapatkan akurasi sebesar $84 \%$ [11]. Sehingga dalam penelitian kali ini, pengembangan penelitian tersebut akan dicoba dengan objek berbeda yaitu citra wajah, untuk kemudian mengkombinasikan proses pra pengolahan, dan teknik ekstraksi fitur serta algoritma pengenalan yang tepat yang dalam hal ini adalah PCA dan Minimum Distance Classifier yang akan menghasilkan tingkat akurasi yang lebih baik dan kurang lebih sama ketika diuji pada lebih dari satu database wajah. Pokok perhatian dalam pengenalan wajah adalah bagaimana mendapatkan karakteristik citra yang dapat membedakan antara wajah satu dengan yang lainnya. Hasilnya merupakan sistem berbasis komputer yang dapat digunakan untuk mengenali wajah dengan menggunakan citra wajah itu sendiri. Dalam penelitian ini, data yang digunakan berasal dari ORL database [12] dan YALE database [13].

\section{METODE PENELITIAN}

Metode penelitian sistem pengenalan wajah menggambarkan tahapan sistematis yang dilakukan dalam mencapai tujuan penelitian. Gambar 1 menunjukkan metode penelitian sistem pengenalan wajah.

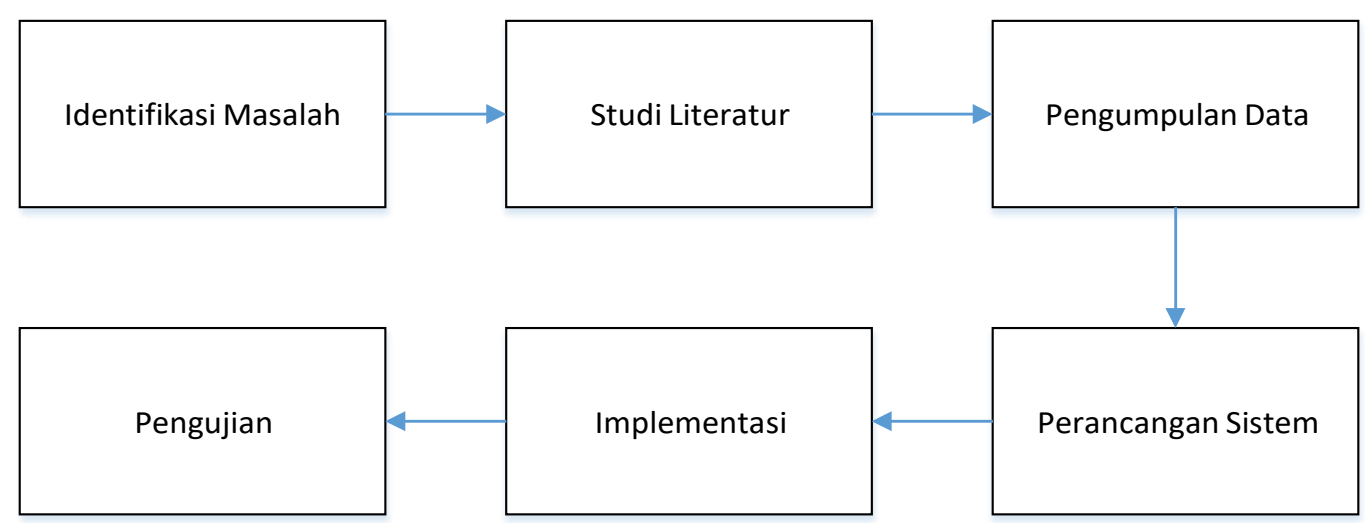

Gambar 1. Metode Penelitian Sistem Pengenalan Wajah

\subsection{Identifikasi Masalah}

Pada tahap ini, peneliti melakukan pengumpulan informasi dari jurnal - jurnal dan teori tentang pengenalan wajah, metode ekstraksi ciri PCA dan metode pengenalan Minumun Distance Classifier.

\subsection{Studi Literatur}

Pada tahapan ini dilakukan proses pembelajaran dari beberapa tinjauan pustaka yang relevan dengan penelitian yang akan dikerjakan. Juga merupakan pengumpulan data dan informasi dari buku-buku referensi, modul-modul, dan artikel-artikel yang sesuai dengan objek penelitian.

\subsection{Pengumpulan Data}

Objek pengenalan pada penelitian ini adalah data berbentuk citra digital yaitu merupakan suatu matriks yang terdiri dari baris dan kolom, dimana setiap pasangan indeks baris dan kolom menyatakan suatu titik pada citra. Nilai matriksnya menyatakan nilai kecerahan titik tersebut. Titik-titik tersebut dinamakan sebagai elemen citra, atau pixel (picture elemen). Data 
citra ini berupa citra dalam bentuk skala keabuan, karena lebih mudah untuk dianalisa dibandingkan dengan citra berwarna.

Pada penelitian ini jenis data yang digunakan berupa data sekunder yang berasal dari database wajah ORL dan YALE. ORL database berisi 400 citra wajah yang terdiri dari 10 citra berbeda dari masing-masing 40 individu berbeda. Sedangkan YALE database yang digunakan yaitu sejumlah 150 citra wajah dari 15 individu berbeda yang masing - masing memiliki 10 citra berbeda di bawah berbagai ekspresi wajah, kondisi pencahayaan, dan gambar dengan dan tanpa kacamata. Citra dari ORL database memiliki resolusi 92 x 112 piksel, dan YALE database dengan resolusi $320 \times 243$ piksel. Namun sebelum masuk ke tahap pra pengolahan, semua citra, baik dari ORL database dan YALE database dinormalisasi ke resolusi $50 \times 50$ piksel.



Gambar 2. Database ORL 


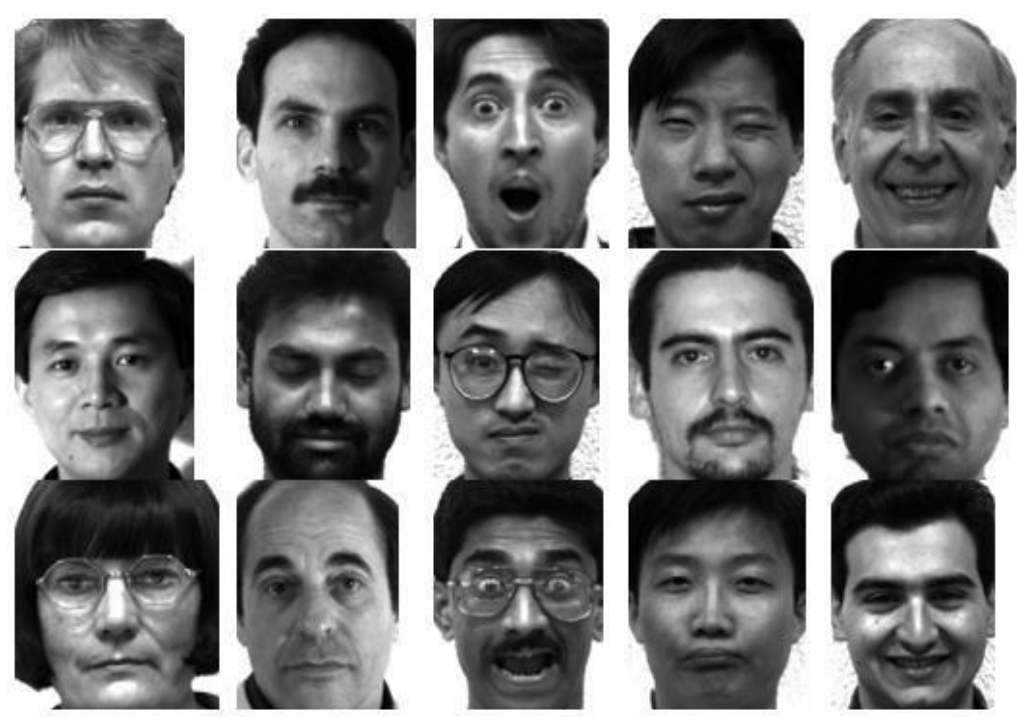

Gambar 3. Database YALE

\subsection{Perancangan Sistem}

Tahap - tahap yang dilakukan dalam sistem pengenalan wajah ditunjukkan oleh gambar yaitu pra-pengolahan, ekstraksi ciri, dan pengenalan. Gambar 4 menunjukkan kerangka kerja sistem pengenalan wajah.

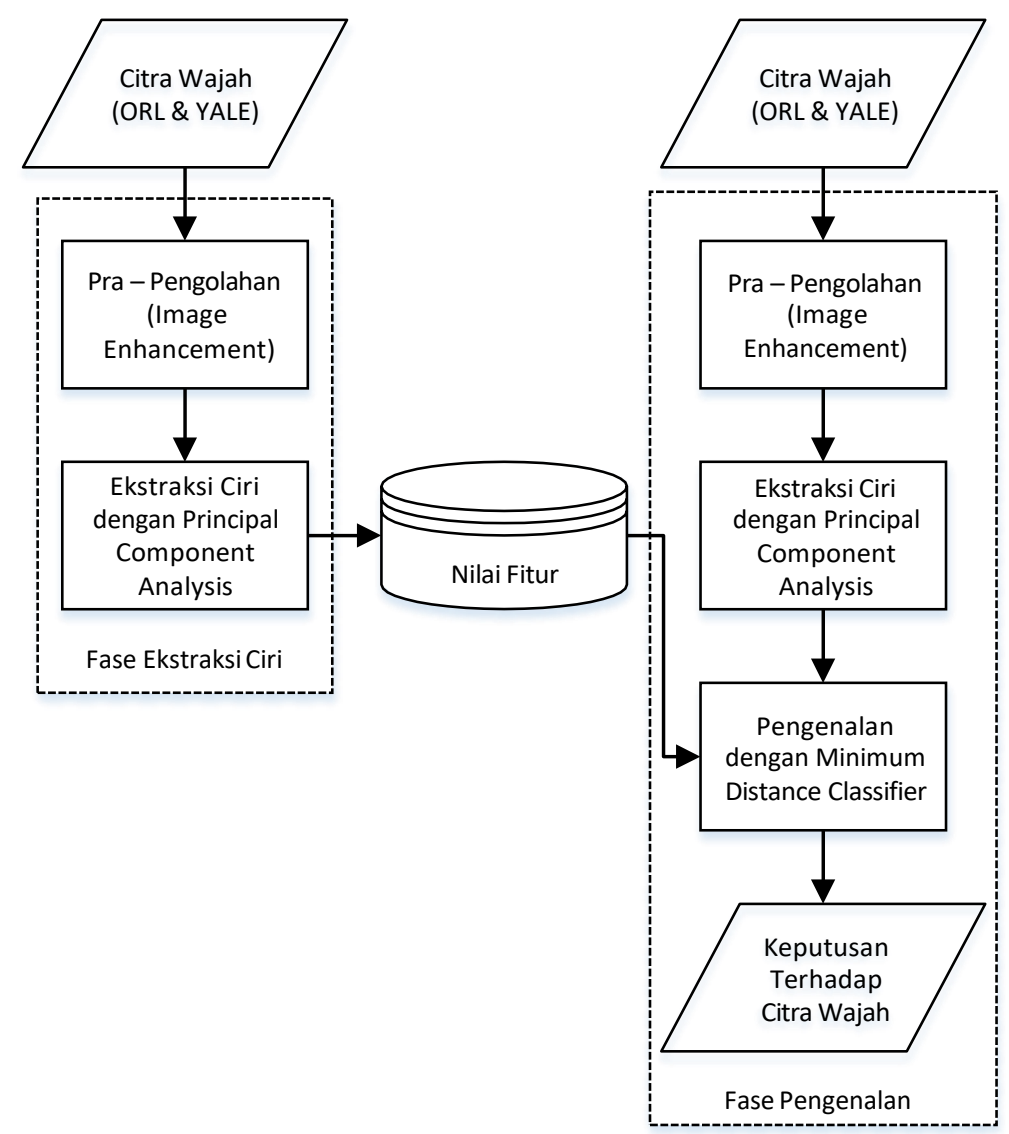

Gambar 4. Perancangan Sistem Pengenalan Wajah 
Pra-pengolahan merupakan tahap awal dalam pengenalan objek yang merupakan proses penelitian dengan menggabungkan konsep citra digital, matematika dan statistik. Semua citra wajah yang diinput akan melalui proses pra pengolahan terlebih dahulu. Dalam penelitian ini terdapat dua tahap pra-pengolahan, yaitu proses image enhancement berupa pengaturan brightness dan contrast. Fungsi brightness dan contrast adalah untuk membersihkan citra sehingga citra yang akan mengalami proses pengenalan akan lebih mudah untuk dideteksi. Kecerahan citra diperbaiki dengan menambahkan / mengurangkan sebuah konstanta kepada (atau dari) setiap pixel. Begitu pula dengan perbaikan kontras setiap citra masukan, sehingga semua citra masukan dapat memiliki standar kecerahan dan standar kontras yang sama agar proses ekstraksi ciri menggunakan Principal Component Analysis dapat dilakukan dengan lebih optimal. Gambar 5 menunjukkan hasil pra pengolahan.

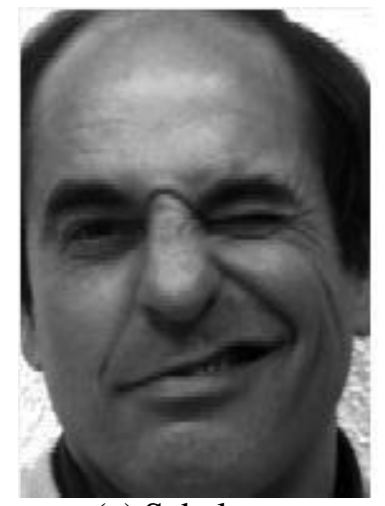

(a) Sebelum

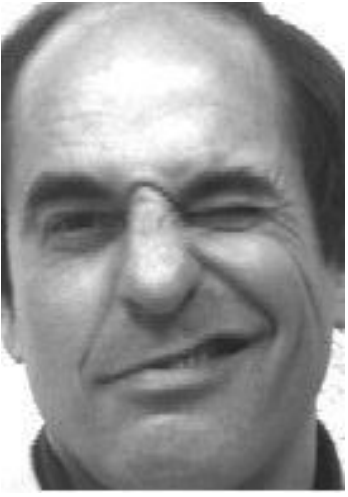

(b)Sesudah

Gambar 5. Hasil Pra Pengolahan Citra Wajah

Ekstraksi ciri dengan PCA bertujuan untuk mendapatkan eigenvector dari tiap citra yang berfungsi sebagai ciri dari masing - masing citra wajah tersebut. Tahapan ekstraksi ciri dengan PCA ditunjukkan pada gambar 6.

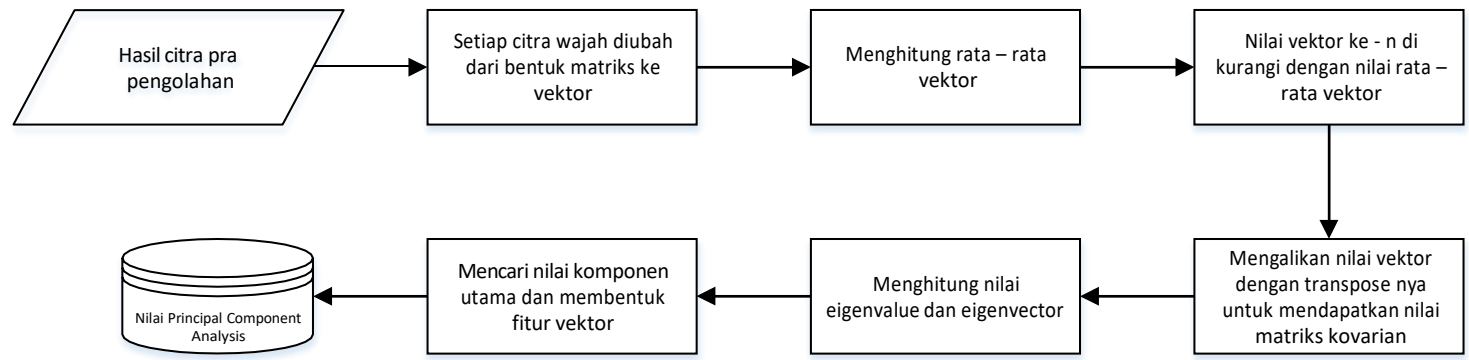

Gambar 6. Tahap Ekstraksi Ciri dengan Principal Component Analysis

Setelah ciri didapat, nilai ciri tersebut akan dikenali menggunakan algoritma Minimum Distance Classifier. Pada tahap pengenalan wajah, nilai dari citra yang akan dikenali akan diproyeksikan terhadap nilai fitur yang telah di dapat pada tahap sebelumnya dengan mencari jarak terdekatnya, lalu dari hasil perhitungan tersebut akan didapatkan keluaran berupa keputusan terhadap citra wajah mana yang paling mendekati citra wajah yang diinputkan.

\subsection{Implementas}

Implementasi dilakukan berdasarkan hasil perancangan pada tahap sebelumnya dengan menggunakan bahasa pemrograman Java.

Putri, et., al [Pengenalan Wajah Menggunakan Minimum Distance Classifier Berdasarkan Fitur Principal Component Analysis] 


\subsection{Pengujian}

Untuk mencapai pengenalan yang tinggi dan kehandalan sistem dibutuhkan metode yang mampu menempatkan keyakinan lebih tinggi untuk memperbaiki hasil pengenalan. Metode ini dapat terdiri dari pengimplementasian fungsi sederhana dari parameter yang tepat diambil langsung dari proses pengenalan. Persamaan (1) dan (2) merupakan beberapa kriteria dalam mengukur kemampuan sistem mengenali citra:

Mis-recognition Rate (MR) didefinisikan dengan :

$$
M R=\frac{\text { number of misrecognize sample }}{\text { total number of test sample }} \times 100 \%
$$

Recognition Rate (RR) atau kehandalan sistem didefinisikan dengan :

$$
R R=\frac{\text { total number of test sample-number of misrecognize sample }}{\text { total number of test sample }} \times 100
$$

\section{HASIL DAN PEMBAHASAN}

Terdapat 2 jenis pengujian yang dilakukan pada penelitian ini berdasarkan sampel citra wajah yang diuji, yaitu:

1. Pengujian data citra dengan menggunakan database ORL.

2. Pengujian data citra dengan menggunakan database YALE.

\subsection{Pengujian Data Citra dengan Menggunakan Database ORL}

Pengujian ini menggunakan database ORL dengan jumlah data 200 citra wajah. Hasil persentase pengujian ditunjukkan pada Tabel 1 .

\begin{tabular}{|c|c|c|c|c|c|c|}
\hline \multirow[b]{2}{*}{$\begin{array}{l}\text { Data } \\
\text { Citra }\end{array}$} & \multicolumn{5}{|c|}{ Dikenali sebagai } & \multirow{2}{*}{$\begin{array}{l}\text { Persentase } \\
\text { Pengenalan }\end{array}$} \\
\hline & $\begin{array}{c}\text { Citra } s(n) \\
1\end{array}$ & $\begin{array}{c}\text { Citra } s(n) \\
2\end{array}$ & $\begin{array}{c}\text { Citra s(n) } \\
3\end{array}$ & $\begin{array}{c}\text { Citra } s(n) \\
4\end{array}$ & $\begin{array}{c}\text { Citra } s(n) \\
5\end{array}$ & \\
\hline s1 & $\mathrm{s} 1$ & $\mathrm{~s} 1$ & s1 & $\mathrm{s} 1$ & $\mathrm{~s} 1$ & $100 \%$ \\
\hline s2 & s2 & s2 & s2 & s2 & s2 & $100 \%$ \\
\hline s3 & s3 & s3 & s3 & s3 & s3 & $100 \%$ \\
\hline s4 & s4 & s4 & s4 & s4 & s4 & $100 \%$ \\
\hline s5 & s40 & s5 & s5 & s5 & s5 & $80 \%$ \\
\hline s6 & s6 & s6 & s6 & s6 & s6 & $100 \%$ \\
\hline s7 & s7 & s7 & s7 & s7 & s7 & $100 \%$ \\
\hline s8 & s8 & s8 & s8 & s8 & $\mathrm{s}$ & $100 \%$ \\
\hline s9 & s9 & s9 & s9 & s9 & s9 & $100 \%$ \\
\hline s10 & s10 & s10 & s10 & s10 & s10 & $100 \%$ \\
\hline s11 & s11 & s11 & s11 & s11 & s11 & $100 \%$ \\
\hline s12 & s12 & s12 & s12 & s12 & s12 & $100 \%$ \\
\hline s13 & s13 & s13 & s13 & s13 & s13 & $100 \%$ \\
\hline s14 & s14 & s14 & s14 & s14 & s14 & $100 \%$ \\
\hline s15 & s15 & s15 & $\mathrm{s} 15$ & s15 & s15 & $100 \%$ \\
\hline s16 & s16 & s16 & s16 & s16 & s16 & $100 \%$ \\
\hline
\end{tabular}

Tabel 1. Hasil Pengujian Menggunakan Database ORL 


\begin{tabular}{|c|c|c|c|c|c|c|}
$\mathrm{s} 17$ & $\mathrm{~s} 17$ & $\mathrm{~s} 17$ & $\mathrm{~s} 17$ & $\mathrm{~s} 17$ & $\mathrm{~s} 17$ & $100 \%$ \\
\hline $\mathrm{s} 18$ & $\mathrm{~s} 12$ & $\mathrm{~s} 18$ & $\mathrm{~s} 18$ & $\mathrm{~s} 18$ & $\mathrm{~s} 18$ & $80 \%$ \\
\hline $\mathrm{s} 19$ & $\mathrm{~s} 19$ & $\mathrm{~s} 19$ & $\mathrm{~s} 19$ & $\mathrm{~s} 19$ & $\mathrm{~s} 19$ & $100 \%$ \\
\hline $\mathrm{s} 20$ & $\mathrm{~s} 20$ & $\mathrm{~s} 20$ & $\mathrm{~s} 20$ & $\mathrm{~s} 20$ & $\mathrm{~s} 20$ & $100 \%$ \\
\hline $\mathrm{s} 21$ & $\mathrm{~s} 21$ & $\mathrm{~s} 21$ & $\mathrm{~s} 21$ & $\mathrm{~s} 21$ & $\mathrm{~s} 21$ & $100 \%$ \\
\hline $\mathrm{s} 22$ & $\mathrm{~s} 22$ & $\mathrm{~s} 22$ & $\mathrm{~s} 22$ & $\mathrm{~s} 22$ & $\mathrm{~s} 22$ & $100 \%$ \\
\hline $\mathrm{s} 23$ & $\mathrm{~s} 23$ & $\mathrm{~s} 23$ & $\mathrm{~s} 23$ & $\mathrm{~s} 23$ & $\mathrm{~s} 23$ & $100 \%$ \\
\hline $\mathrm{s} 24$ & $\mathrm{~s} 24$ & $\mathrm{~s} 24$ & $\mathrm{~s} 24$ & $\mathrm{~s} 24$ & $\mathrm{~s} 24$ & $100 \%$ \\
\hline $\mathrm{s} 25$ & $\mathrm{~s} 25$ & $\mathrm{~s} 25$ & $\mathrm{~s} 25$ & $\mathrm{~s} 25$ & $\mathrm{~s} 25$ & $100 \%$ \\
\hline $\mathrm{s} 26$ & $\mathrm{~s} 26$ & $\mathrm{~s} 26$ & $\mathrm{~s} 26$ & $\mathrm{~s} 26$ & $\mathrm{~s} 26$ & $100 \%$ \\
\hline $\mathrm{s} 27$ & $\mathrm{~s} 27$ & $\mathrm{~s} 27$ & $\mathrm{~s} 16$ & $\mathrm{~s} 27$ & $\mathrm{~s} 27$ & $80 \%$ \\
\hline $\mathrm{s} 28$ & $\mathrm{~s} 28$ & $\mathrm{~s} 28$ & $\mathrm{~s} 28$ & $\mathrm{~s} 28$ & $\mathrm{~s} 28$ & $100 \%$ \\
\hline $\mathrm{s} 29$ & $\mathrm{~s} 29$ & $\mathrm{~s} 29$ & $\mathrm{~s} 29$ & $\mathrm{~s} 29$ & $\mathrm{~s} 29$ & $100 \%$ \\
\hline $\mathrm{s} 30$ & $\mathrm{~s} 30$ & $\mathrm{~s} 30$ & $\mathrm{~s} 30$ & $\mathrm{~s} 30$ & $\mathrm{~s} 30$ & $100 \%$ \\
\hline $\mathrm{s} 31$ & $\mathrm{~s} 31$ & $\mathrm{~s} 31$ & $\mathrm{~s} 31$ & $\mathrm{~s} 34$ & $\mathrm{~s} 31$ & $80 \%$ \\
\hline $\mathrm{s} 32$ & $\mathrm{~s} 32$ & $\mathrm{~s} 32$ & $\mathrm{~s} 32$ & $\mathrm{~s} 32$ & $\mathrm{~s} 32$ & $100 \%$ \\
\hline $\mathrm{s} 33$ & $\mathrm{~s} 33$ & $\mathrm{~s} 33$ & $\mathrm{~s} 33$ & $\mathrm{~s} 33$ & $\mathrm{~s} 33$ & $100 \%$ \\
\hline $\mathrm{s} 34$ & $\mathrm{~s} 34$ & $\mathrm{~s} 34$ & $\mathrm{~s} 34$ & $\mathrm{~s} 34$ & $\mathrm{~s} 34$ & $100 \%$ \\
\hline $\mathrm{s} 35$ & $\mathrm{~s} 35$ & $\mathrm{~s} 35$ & $\mathrm{~s} 35$ & $\mathrm{~s} 11$ & $\mathrm{~s} 35$ & $80 \%$ \\
\hline $\mathrm{s} 36$ & $\mathrm{~s} 36$ & $\mathrm{~s} 36$ & $\mathrm{~s} 36$ & $\mathrm{~s} 36$ & $\mathrm{~s} 36$ & $100 \%$ \\
\hline $\mathrm{s} 37$ & $\mathrm{~s} 37$ & $\mathrm{~s} 37$ & $\mathrm{~s} 28$ & $\mathrm{~s} 37$ & $\mathrm{~s} 37$ & $80 \%$ \\
\hline $\mathrm{s} 38$ & $\mathrm{~s} 38$ & $\mathrm{~s} 38$ & $\mathrm{~s} 38$ & $\mathrm{~s} 38$ & $\mathrm{~s} 38$ & $100 \%$ \\
\hline $\mathrm{s} 39$ & $\mathrm{~s} 39$ & $\mathrm{~s} 39$ & $\mathrm{~s} 39$ & $\mathrm{~s} 39$ & $\mathrm{~s} 39$ & $100 \%$ \\
\hline $\mathrm{s} 40$ & $\mathrm{~s} 40$ & $\mathrm{~s} 40$ & $\mathrm{~s} 40$ & $\mathrm{~s} 40$ & $\mathrm{~s} 40$ & $100 \%$ \\
\hline & & Rata - rata Persentase & & & $\mathbf{9 7 \%}$ \\
\hline
\end{tabular}

Tabel 1 memperlihatkan hasil pengujian yang menggunakan dataset sebanyak 200 citra wajah dari ORL database. Persentase hasil pengujian menggunakan ORL database sebesar $97 \%$, dikarenakan 3\% dari jumlah data pengujian atau sebanyak 6 citra wajah dari total 200 citra wajah tidak berhasil dikenali / keluaran dari sistem tidak sesuai dengan apa yang diharapkan. Perhitungan persentase menggunakan persamaan (1) \& (2).

$$
\begin{gathered}
\text { Mis-recognition Rate }(\mathrm{MR}): \\
M R=\frac{6}{200} \times 100 \%=3 \% \\
R R=\frac{200 \text { Reconition Rate }(\mathrm{RR}):}{200} \times 100 \%=97 \%
\end{gathered}
$$

\subsection{Pengujian Data Citra dengan Menggunakan Database YALE}

Pengujian ini menggunakan database YALE dengan jumlah data 75 citra wajah. Hasil persentase pengujian ditunjukkan pada Tabel 2. 
Tabel 2. Hasil Pengujian Menggunakan Database YALE

\begin{tabular}{|c|c|c|c|c|c|c|}
\hline \multirow{2}{*}{$\begin{array}{c}\text { Data } \\
\text { Citra }\end{array}$} & \begin{tabular}{c} 
Subject(n) \\
\cline { 2 - 5 }
\end{tabular} & $\begin{array}{c}\text { Subject(n) } \\
\mathbf{2}\end{array}$ & $\begin{array}{c}\text { Subject(n) } \\
\mathbf{3}\end{array}$ & $\begin{array}{c}\text { Subject(n) } \\
\mathbf{4}\end{array}$ & $\begin{array}{c}\text { Subject(n) } \\
\mathbf{5}\end{array}$ & $\begin{array}{c}\text { Persentase } \\
\text { Pengenalan }\end{array}$ \\
\hline subject01 & subject01 & subject01 & subject01 & subject01 & subject01 & $100 \%$ \\
\hline subject02 & subject02 & subject02 & subject02 & subject02 & subject02 & $100 \%$ \\
\hline subject03 & subject03 & subject03 & subject03 & subject03 & subject03 & $100 \%$ \\
\hline subject04 & subject04 & subject04 & subject04 & subject04 & subject04 & $100 \%$ \\
\hline subject05 & subject05 & subject05 & subject05 & subject05 & subject05 & $100 \%$ \\
\hline subject06 & subject06 & subject06 & subject06 & subject06 & subject06 & $100 \%$ \\
\hline subject07 & subject10 & subject07 & subject10 & subject07 & subject07 & $60 \%$ \\
\hline subject08 & subject08 & subject08 & subject08 & subject08 & subject08 & $100 \%$ \\
\hline subject09 & subject09 & subject09 & subject09 & subject09 & subject09 & $100 \%$ \\
\hline subject10 & subject10 & subject10 & subject10 & subject14 & subject10 & $80 \%$ \\
\hline subject11 & subject11 & subject11 & subject11 & subject11 & subject11 & $100 \%$ \\
\hline subject12 & subject12 & subject12 & subject12 & subject12 & subject12 & $100 \%$ \\
\hline subject13 & subject13 & subject13 & subject13 & subject13 & subject13 & $100 \%$ \\
\hline subject14 & subject14 & subject14 & subject14 & subject14 & subject14 & $100 \%$ \\
\hline subject15 & subject15 & subject15 & subject15 & subject14 & subject15 & $80 \%$ \\
\hline \multicolumn{7}{|c|}{ Rata - rata Persentase } \\
\hline
\end{tabular}

Tabel 2 memperlihatkan hasil pengujian data uji yang menggunakan data berbeda dari data latih yaitu sebanyak 75 citra wajah dari YALE database. Persentase hasil pengujian menggunakan YALE database sebesar 94,67\%, dikarenakan 5,33\% dari jumlah data pengujian atau sebanyak 4 citra wajah dari total 75 citra wajah tidak berhasil dikenali / keluaran dari sistem tidak sesuai dengan apa yang diharapkan. Perhitungan persentase menggunakan rumus (1) \& (2).

$$
\begin{gathered}
\text { Mis-recognition Rate }(\mathrm{MR}): \\
M R=\frac{4}{75} \times 100 \%=5,33 \% \\
R R=\frac{75-4}{75} \times 100 \%=94,67 \%
\end{gathered}
$$

\section{KESIMPULAN}

Berdasarkan hasil analisa yang dilakukan pada penelitian ini, maka dapat diambil kesimpulan bahwa penambahan proses pra pengolahan yang tepat dapat meningkatkan akurasi pengenalan, dan metode yang diusulkan dapat mengenali dengan baik pada lebih dari satu database citra wajah. Hasil pengujian yang didapat dengan menggunakan data dari ORL database memberikan keakuratan sebesar 97\% sedangkan hasil pengujian dengan menggunakan data dari YALE database memberikan keakuratan sebesar $94,67 \%$. 


\section{SARAN}

Adapun saran yang dapat diberikan adalah sebagai berikut:

1. Untuk menangkap informasi lebih tepat tentang citra wajah, beberapa jenis fitur yang sesuai dengan sistem pengenalan wajah dapat diusulkan.

2. PCA diharapkan dapat dikembangkan untuk memilih jumlah optimal eigenvector untuk pengenalan yang lebih baik dan untuk memecahkan masalah pengenalan buah dalam tingkat yang lebih bervariatif di penelitian selanjutnya.

3. Menambah proses pra pengolahan lain yang dianggap mampu meningkatkan kualitas citra wajah.

\section{DAFTAR PUSTAKA}

[1] M. Satone and G. Kharate. 2014, "Feature Selection Using Genetic Algorithm for Face Recognition Based on PCA, Wavelet and SVM," Int. J. Electr. Eng. Informatics, Vol. 6, No. 1, pp. 39-52, doi: 10.15676/ijeei.2014.6.1.3.

[2] C. Ding and D. Tao. 2017, "Pose-Invariant Face Recognition with Homography-Based Normalization," Pattern Recognit., Vol. 66, No. July, pp. 144-152, doi: 10.1016/j.patcog.2016.11.024.

[3] C. Zhou, L. Wang, Q. Zhang, and X. Wei. 2014, "Face Recognition Based on PCA and Logistic Regression Analysis, $\|$ Optik (Stuttg)., Vol. 125, No. 20, pp. 5916-5919, doi: 10.1016/j.ijleo.2014.07.080.

[4] S. Singh and S. V. A. V. Prasad. 2018, "Techniques and Challenges of Face Recognition: A Critical Review," Procedia Comput. Sci., Vol. 143, pp. 536-543, doi: 10.1016/j.procs.2018.10.427.

[5] R. Sharma and M. S. Patterh. 2015, “A New Pose Invariant Face Recognition System Using PCA and ANFIS,” Optik (Stuttg)., Vol. 126, No. 23, pp. 3483-3487, doi: 10.1016/j.ijleo.2015.08.205.

[6] S. Bag and G. Sanyal. 2011, "An Efficient Face Recognition Approach Using PCA and Minimum Distance Classifier," ICIIP 2011 - Proc. 2011 Int. Conf. Image Inf. Process., No. Iciip, pp. 0-5, doi: 10.1109/ICIIP.2011.6108906.

[7] M. P. Gawande and P. D. G. Agrawal. 2014, "Face Recognition Using PCA and Different Distance Classifiers," IOSR J. Electron. Commun. Eng., Vol. 9, No. 1, pp. 0105, doi: 10.9790/2834-09160105.

[8] N. Khan and M. Gupta. 2016, "Face Recognition System Using Improved Artificial Bee Colony Algorithm," Int. Conf. Electr. Electron. Optim. Tech. ICEEOT 2016, pp. 37313735, doi: 10.1109/ICEEOT.2016.7755408.

[9] A. H. Sable and S. N. Talbar. 2016, "A Novel Illumination Invariant Face Recognition Method Based on PCA and WPD Using YCbCr Color Space," Procedia Comput. Sci., Vol. 92, pp. 181-187, doi: 10.1016/j.procs.2016.07.344. 
[10] S. C. Satapathy, V. Bhateja, S. K. Udgata, and P. K. Pattnaik. 2017, -Preface,” Adv. Intell. Syst. Comput., Vol. 515, pp. v-vii, doi: 10.1007/978-981-10-3153-3.

[11] V. No and B. A. Putri, "Penggunaan Principal Component Analysis dan Minimum Distance Classifier Untuk Pengenalan Citra Buah," Vol. 2, No. 1, pp. 355-358, 2016.

[12] Cambridge University Engineering Department. 2001, "The Database of Faces," AT\&T Laboratories Cambridge, https://cam-orl.co.uk/facedatabase.html (accessed Jan. 11, 2017).

[13] UCSD Jacobs School of Engineering. 2020, "YALE Face Database," UCSD Computer Vision, 2011. http://vision.ucsd.edu/content/yale-face-database (accessed Jan. 29, 2020). 